\title{
Bovine Congenital Erythropoietic Porphyria
}

National Cancer Institute

\section{Source}

National Cancer Institute. Bovine Congenital Erythropoietic Porphyria. NCI Thesaurus.

Code C131470.

A cong enital metabolic disorder characterized by a deficiency in the enzyme uroporphyrinogen III synthase, which occurs in cattle. 